\title{
LEARNING ORGANIZATION AS RESPONSIVE BEHAVIOR TOWARD THE POLICIES OF HIGHER EDUCATION QUALITY IMPROVEMENT
}

\author{
Hanafiah $^{1}$, Hendi S. Muchtar ${ }^{2}$ \\ ${ }^{1}$ Nusantara Islamic University, Bandung \\ ${ }^{2}$ Nusantara Islamic University, Bandung
}

\begin{abstract}
The development of higher education quality becomes primary activities that are not negotiable. Various government policies on the development of higher education continue to be issued, such as the Laws of Higher Education, Quality Assurance System of Higher Education, and the National Standards for Higher Education. One of responsive behavior to the development of quality higher education that is the Learning Organization. Through learning organization, every policies relating to the development have been discussed formally as well as becoming the means of improving the capacity of human resources in higher education adaptively and generatively. Learning organization originated from the culture of individual and team learning. This has led to shape the betterment of the quality of higher education, and also in responding to the policies of the development of quality higher education. The authors propose the alternative tools for that matter, that is the fifth disciplines of learning organization from Peter Senge, et al., namely: (1) Systems Thinking, (2) Personal Mastery; (3) Mental Models; (4) Shared Vision; and (5) Team Learning. Approach of Learning Organization in response to the policy of the development of quality higher education is done through internal dynamics, analysis of daily problems, self renewal capacity, building competitiveness in a cooperative and, build healthy higher education in the midst of rapid environmental changes, complex, and dynamic.
\end{abstract}

Keywords: higher education, quality improvement, learning organization

\section{INTRODUCTION}

Higher education institutions in Indonesia are growing and developing so fast, from the capital city, province, city district down to the district level. This is in line with the speech the Director General of Learning and Student Affairs in Higher Education at UNPAR Anniversary on Monday, 18 January 2016, that states, "Development of Higher Education in Indonesia in the last decade grew significantly." He also noted that in late of 2015 the institutions of Higher Education in Indonesia have reached to 4,388. This amount is more than all of higher education institution in Europe. He also added that the needs of higher education institution in Indonesia are boldness in actualizing the mission differentiation. Through this act, it can be developed several policies to reform the system of higher education and research.

Based on the government databases of recapitulation in the half of 2015/2016, there are 370 state higher education institution in Indonesia, whereas for private higher education institution recorded to 4,043. Meanwhile, the number of lecturers according to national recap at the second semester of 2015/2016 mentioned that the number of lecturers in state higher education institution amounted to 90742 lecturers and in private higher education institution amounted to 160.159 . 
Higher Education Quality Development policy continues to improve, but it has double impacts. On one hand, it manifested into strengths and opportunities, but on the other hand it manifested into threat and also weakening the existence of higher education, especially private higher education institution, where private higher education institution progress is fluctuating, which originated from the situation regularly shifted negative to the complexity, and the next crisis - decline, turbulance, and to the point of chaos, and then even death. The Ministry has announced, which launched the site AyoKuliah on February 26, 2016 as follows: "There are 243 higher education institution caught in troubles or do not meet the healthy campus indicators, namely 228 higher education institutions in Kemenristekdikti and 15 higher education institutions in the Ministry of Religion. Furthermore, some higher education institutions were forced to closed and revoked up to 103 licenses. On the other hand, Kemenristekdikti mentioned that ITB and UI has classified into top 500 higher education institutions of the world. In addition, those which is being targeted to enter top 500 in the world are: UGM in 2016; IPB in 2018 and UNAIR in 2019.

The disparity in development and deterioration of the quality of higher education must be responded critically learning organization, effective, innovative and accountable. Through learning organization in response to the higher education institution's quality policy development is expected to impact positively for the creation of multi empowerment cultivation and improvement of human resource capabilities are critical, creative, effective, innovative, adaptive and accountable. So the future of higher education quality becomes better. The learning organization can grow flowers beginning with the Individual Learning that acculturation and empowerment of increasing the capability of self-made individually, as well as Team learning is a civilizing and increasing the capability of self empowerment that done in groups.

Learning Organization approach in this case is an alternative solution in response to the development of quality higher education policy, because only a learning organization that is able to respond adaptively higher education institution's existence. Learning organization in response to the policy of the development of quality education steeper done through internal dynamics, their analysis of daily problems, with the self renewal capacity, building competitiveness, establish cooperative building and organization-building higher education institution in a healthy organization, in the midst of rapid environmental changes, complex, and dynamic.

Learning organization can respond to the higher education institution's quality policy development that is done in an adaptive and generative ways. Adaptively namely the development of quality higher education is reactive, according to the limits of what they can (status quo) is essential to survive in accordance with the factual minimum standards. While the development of the generative, namely the development of quality higher education as a visionary in which higher education institution can survive and proactively creating innovative and superior quality of higher education in cooperative, competitive and comparative within the framework of a local, national, and global.

\section{Problem Formulation}

1. How does the aspects of Learning Organization respond to the policies of higher education quality development?

2. How is the classification of higher education quality development? 
3. Which higher education institution that can be termed as healthy organization?

\section{Benefit}

Through the learning organization, the higher education institution will be able to respond to the policy of quality development that issued by the government and the higher education institution themselves.

\section{THEORETICAL FOUNDATION Learning Organization Definition}

Learning Organization in higher education institution is a process of increasing the capability of human resources in order to create the future of higher education which is better done through internal dynamics, analysis of daily problems, to renew itself from within (self renewal capacity), building competitiveness, cooperative and build a healthy organization, in the midst of rapid environmental changes, complex, and dynamic. Garvin (2000: 11) states: :Learning organization is an organization skilled creating, acquiring, interpreting, transfering and retaining knowledge, and at purposefully modifying its behavior to reflect new knowledge and insight."

Evolving whether the higher education institution's quality is determined by the capability of higher education institution to respond to various internal and external policy changes are adaptive and generative. learning organization visionary higher education institution learning organization makes a driving force for the development of quality higher education is superior to competitive and cooperative sustainable manner (continuous quality improvement).

Learning organization is one form of higher education institution intelligence to adjust various aspects of the spiritual (self adjustment) or the material aspect (self-adaptive) against a variety of internal and external policies which are called autoplastis and alloplastis. (1) Autoplastis namely higher education institution proactively developing quality by adjusting to changes in the surrounding environment. This approach can be done by higher education institution when the position of higher education institution is being driven by the market (controlled environment). (2) Alloplastis namely higher education institution to proactively change the environment in accordance with the high quality standards pergruan. With this approach, when posisis higher education institution is becoming a market leader in order to become a market driver, (control environment).

Learning organization is one form of higher education institution intelligence to adjust various aspects of the spiritual (self adjustment) or the material aspect (self-adaptive) against a variety of internal and external policies which called autoplastis and alloplastis. (1) Autoplastis namely higher education institution is proactively developing quality by adjusting to changes in the surrounding environment. This approach can be done by the institution when its position is driven by market (controlled environment). (2) Alloplastis namely higher education institution to proactively change the environment in accordance with the quality standards of the higher education institution. With this approach, when higher education institution position is becoming a market leader in order to become a market driver (control environment). 
The process of learning organization in response to internal and external policy development of quality higher education can be done invention or discovery. (1) The invention is a process of learning organization devoted to developing the quality of higher education by finding new findings and have not found at all in other places. (2) discovery is the process of learning organization devoted to developing the quality of higher education by finding new findings but had been found elsewhere.

\section{Five Disciplines of Learning Organization}

Driving force is to stimulate and trigger in response to policy development of quality higher education, learning organization built integrally include: personal skill-based organizations, mental models based on openness, a shared vision-based environment, team learning based on participative leadership and systems thinking based solutions in response to rapid environmental changes, complex and dynamic.

\section{Systems Thinking}

Systems Thinking is a way of looking intelligently, in thinking in order to describe and explain all of the components to each other are integrally related to each other, support each other, encourage each other, synergize with each other so that a chain of power systems in achieving the vision of the goals and objectives that have been determined.

Peter M. Senge et al. which is translated by Suminto (2002: 11) states: Systems Thinking way of thinking and language to describe and understand the strengths and interpersonal relationships that shape the behavior of the system. This discipline helps us see how to change systems more effectively and act more in tune with the larger process.

System approach to thinking in higher education institution can assist in finding alternative solutions in a planned breakthrough mapped, integral and sustainable in order to develop higher education quality, namely in the fields of education, research and community service are superior cooperative, comparative and competitive.

\section{Personal Mastery}

Personal Mastery is learning to expand their personal capacity in both the qualification and competence so significantly positive impact on the development of the organization. Peter M. Senge et al. which is translated by Suminto (2002: 10-11) states: "Personal Skills - Learning to increase personal capacity to create the most desired result and create an organizational environment that encourages its members to develop themselves toward the goals and objectives they choose."

Personal mastery is manifested by their individual learning into the culture of everyday life in to his work with the approach of the planning process (Plan), test piloted (Do), check the results of limited testing and revising the repair (Check) so it could be a plan of action viable and worthy to do (Action).

Personal Mastery of higher education institution when professionally managed a major impact on the development of quality higher education is dynamic and can cultivate the entire personnel to develop themselves according to the demands of the job characteristics and thus creating the right man on the right place. 
Personal Mastery in higher education is a discipline that demonstrates the ability to continually clarify and deepen personal vision, focusing energies, developing patience, and see reality objectively. The entire work and learning activities synergized into one whole force for the development of the higher education institution's quality adaptive and generative line of vision, goals and objectives expected. Learning organizations require personnel with high qualifications and competence in order to develop the quality of higher education in an adaptive and generative.

Personal Mastery in higher education needs to be developed in a sustainable manner both in managerial skills, tehnical skill and communication skill. (1) managerial skill, the ability, among others, relating to: the ability to lead, plan, organize, supervise, evaluate, do the decision making, the ability of futuristic thinking, team work, problem solving, and resolve conflicts; (2) Technical skills: the ability, among others, relating to the ability to use and improve certain tools are technically operational, (3) communication skill is the ability, among others, relating to: the ability to relate vertically, ability to relate to partner positions horizontal, ability to relate to subordinates, the ability to communicate interpersonal, negotiating, customer and stakeholder (4) the control of information systems (e.g. find out information duties and responsibilities of the job, knowing the information duties and responsibilities of its partners, informed vision, mission, goals, strategies, objectives, policies carried organization; controls the information segment of the market, knowing the position information of the achievements and prestige of the organization compared to other organizations).

Developing Personal Mastery in higher education institution must continue to do given the speed of change of job characteristics, often comparable straight to the changing policies of state institutions, institutions of the world, as well as science, technology, and have a significant impact on the fluctuation of higher education institution so that forced the organization should review the back: (1) whether a particular job is no longer needed by the organization because it was replaced by a new type of work because it is no longer relevant to the needs of internal and external organizations; (2) should be the development of a job that requires the use of technology; (3) the need for the expansion of cultivated fields on one job (job-enlargement), (4) the need for rotation of office (mutations employees) in order to expand the horizons of knowledge, experience and competence of personnel in units of other work (5) to cultivate awareness coordination, integration, synchronization and simplification among personnel.

The development of personal mastery in higher education institution should be a culture of everyday life, which must be realized, and is believed to be considering the human resources are the basic capital in the human (human investment) which can be a driving force (impetus) for the advancement of organizational development of quality higher education and become magnetic force (attraction) for cuntomer and environmental stakeholders in local, national and global.

\section{Mental Models}

Mental models are the reflection process, clarify and improve the high self-image of the outside world and see how to shape decisions and actions are adaptive and generative. Peter Senge et al. which been translated by Suminto (2002: 11) states: Mental Models - ponder continually, clarify, improve internal picture of the world, and see how it's shaping our actions and decisions. 
The mental models in higher education related to how to think deeply about why and how to take action in developing higher education quality. Mental model of higher education is a map-making or higher education framework model to see how to approach the problems that it faces. In other words, mental models of higher education can be regarded as self-concept higher education institution, which became the basis in making the best decision.

Mental Models of higher education institution is an alternative breakthrough to dissect the mental barriers of passive, towards mental creative, developing individual consciousness toward the collective consciousness, developing local insight into insight, national and global probable model of higher education should be able to cultivate Soft skill personal organization of higher education institution, among others in the aspect of faith, discipline, responsibility, loyalty, obedience, ability to manage emotions, creativity, flexibility, empathy, simpathy, self-awareness, and self-confidence because a capital base in the development of quality higher education adaptively and generatively.

\section{Shared Vision}

Shared Vision, is to build a common vision aimed at building the future of better organization, the vision of a long-term goal of the organization and at the same time become a direction along to every member of the organization. Peter M. Senge et al. which been translated by Suminto (2002: 11) states: Shared Vision - "build commitment within the group, to create a shared picture of the future, and the principles and practices guiding the future to achieve it."

This vision is to be done effectively can be translated into operational objectives and further more can be translated into annual goals or targets. This is in line with the opinion of John Reding and Ralph Catalanello quoted George L Morrisey (1996: 62) states: "The organization of learners trying to apply a clear strategic direction and loose enough so as to allow freedom of expression and creativity in its implementation. They have a vision that is always growing and evolving. The vision that embodies the essence of the organization as to whether it should have in order to survive in the future. Vision shows that the organization is an active institution that has power over their own fate. Vision is open, to allow a change of direction at a certain moment".

More George L Morrisey (1996: 61), states: "That the vision statement is formulated with either (1) Brief, preferably less than ten words. (2) Attracting attention and memorable. (3) To inspire and challenge. (4) the achievements in the future. (5) Be reliable and consistent with the strategic values and your mission. (6) Serves as a meeting point with all stakeholders, (7) clearly states the essence. (8) concerning as what should your organization. (9) Allows flexibility and creativity in its implementation ".

\section{Team Learning}

Team Learning is a container that bridges organizational development in a sustainable manner (continuous improvement). Team learning is an individual and collective commitment towards the organization. As a hallmark of the team learning is that it works better involve others if necessary in totals (total involvement) aimed at finding alternative solutions to the problems encountered, for intelligence of group will exceed the intelligence of the individual. Peter M Senge et al. which been translated by Suminto (2002: 11) states: Learning Teams change the membership of the conversation and expertise to think collectively, so that the group can be relied upon to develop intelligence and ability greater than individually. Team learning is an alternative strategy in order to provide service as excellent to the customer, so 
the customer is satisfied (customer satisfaction), the customer will remain (customer retention), the customer is satisfied will bring the new customer, the more the customer will then be increasingly provide significant economic benefits to the organization (customer benefit), and further with the customer more profitable, will have a positive impact on the organization will be developed in a sustainable manner.

Team learning is a core strategy of learning organization at the higher education institution where the responsive efforts in the empowerment of human resources to be able and willing to sit side by side with other colleagues for sharing problems, sharing experiences, sharing activity, sharing process, sharing evaluation, sharing solutions and sharing the follow-up in order to translate the policy development of quality higher education. Prajudi Atmosoedirdjo quoted Suprapti and Pranoto (2001: 10) states: "The team is a group that has a commitment of mind and harmonious interaction spur changes in the growth and development of personal and organizational commitment and harmonious interaction will appear in integration in the pattern thought (way of thinking), emotion and motivation patterns (way of feeling) and follow patterns (way of action) ".

Strong Interest that supports the need for team learning in response to the development of quality higher education, among others: (1) the workload will be lighter because of the work carried out jointly by a team which bear the same weight in the same lightweight portable; (2) the occurrence of group learning process in which the sharing problems, sharing, process, sharing experiences, sharing solution, sharing a follow-up; (3) weaknesses of each individual can be overcome by the team, through give and take; (4) the ability to problem-solving relatively more accurate, because with the many contributions of the team with perspectives from different aspects; (5) considering the planning, implementation, evaluation and determine the follow-up by the team, the responsibility will be shared.

Robert B Maddux quoted Suprapti and Pranoto (2001: 12) states Benefits build effective teams is as follows (a). With the team then set realistic goals, and can be reached optimally (b). Team members and leaders have committed to support each other for the team to succeed. (C). Team members understand the priorities of other members and can help each other. (D). Communication is open, discussion of new ways of working or improve walking performance better because the team members are encouraged to think more about the issue. (E) Solving the problem more effectively because of the ability of a team of more adequate $(\mathrm{F})$. Performance feedback is more adequate, because team members know what is expected and can compare their performance to the team goals. (G). Conflict is accepted as a natural thing, and is considered an opportunity to resolve the problem. Through these discussions the conflict can be resolved to the fullest. $(\mathrm{H})$. Balance the achievement of the team's productivity with the fulfillment of personal needs. (I). The team was rewarded for excellent results, and every member praised for his personal contributions. (J). The group members are motivated to bounce ideas off and testing this, as well as transmit and develop his potential to the fullest. (K). group members realize the importance of discipline as work habits and adjusting the behavior to achieve the standard group (1). Group members perform better in cooperation with the team and other teams.

These five dimensions Learning Organization must be present together in a higher education institution organization in order to accelerate the process of organizational learning and improving its ability to translate policy of development of quality higher education in an adaptive and generative amid rapid change, complex and dynamic. 


\section{DEVELOPMENT OF ORGANIZATION}

Learning organization in response to the development of quality higher education policy in an adaptive and generative will have an impact on the organization's development of the higher education institution itself. The development of the organization in general can be grouped as follows: First, the stage Survive. This stage has the characteristic behavior of organizational behavior as follows: (a). maintaining the existing circumstances, (b). relatively limited resources, (c). what their limited market and, (d). idea or breakthrough solutions is still limited. Second, the Growth stage of this stage show the characteristic behavior of organizational behavior as follows: (a). their physical changes, (b) the change in geographic, (c) the quality is still the same as the past, (d) the market is no extension on the same segment, (d) an existing idea or the breakthrough for the more advanced. Third, Profitability stage shows characteristics of organizational behavior as follows: (a) the extension of the geographical market (b) the extension of the product, (c) an increase in quality (d) levels varied market segments. (E) the customer benefits (f) the resources available lots, (f) adequate welfare. Fourth, stage Competitiveness, show the characteristic behavior of the organization as follows: (a) the extension of geographic markets, (b) there are the expansion of the product, (c) an increase in quality (d) the level of market segments varied, (e) Customer 's benefit, (f ) provided a lot of resources (g) adequate welfare, (h) the dynamic and progressive. (I) innovation, (j) the superior cooperative, comparative and competitive. Fifth, Maturity stage show the characteristic behavior of the organization as follows: (a) be a benchmark, (b) become the market leader (c) be a licensor, (d) be a reference to other organizations, (e). stability man, material, money, and market. (F) rely on research and development (g) based on science and technology, (h) based information systems, (i) the existence of equilibrium (balance) between the interests of the organization and personnel.

The Ministry of Higher education determines the classification and ranking of alternative indicators Higher education development in Indonesia in 2015 issued a decree number 492 A / M / Kp / VIII / 2015 include: (1) the quality of Human Resources; (2) the quality of management; (3) the quality of student activities; (4) the quality of research and publications. Another alternative indicator that provided by government determine the best higher education institutions in 2016, presented during a press conference at his office Ministry of Research, Technology and Higher Education, Wednesday, August 17, 2016 include: (1) Lecturer 10\%; (2) the quality of lecturers $18 \%$; (3) the accreditation of $30 \%$; (4) the quality of student activities 10\%; (5) the quality of the research activities of 30\%. As for the ranking is based on the analysis of the data monitored by Ministry of Research, Technology and Higher Education.

\section{HIGHER EDUCATION INSTITUTION AS AN HEALTHY ORGANIZATION}

Learning organization that runs an adaptive, generative and accountable will have a positive impact on the health of an organization. Organization is healthy in general show behavioral indicators, among others: (1) has a vision as a picture of a better future; (2) has a standard activity; (3) open to change is adaptive and generative, (3) the decision-making professionally and proportionately, (4) build teamwork, (5) the dimensions of the individual and the organization built a harmonious and balanced, (6) the failure to be addressed as early learning, ( 7) the participation of under appreciated as a very worthwhile investment, (8) mutual appreciation and respect, (9) the conflict is the dynamic and road building sharing problems, sharing information, sharing experience, sharing solution, and sharing victory, (10) establish coordination, integration, synchronization and simplification, (11) establish situational 
leadership, (12) customer satisfaction (13) just in time, (14) just on time, (15) zero defect, (16) has information broadly-based technology ( 17) all activities are managed properly, quickly, easily and standards.

Meanwhile Higher education institution behavioral indicators of healthy in the environment of Ministry of Research, Technology and Higher Education as stated by Dian Armanto, Coordinator Kopertis, contained in Tirto id, dated May 27, 2016 as follows; (1). Having a license to open the opening of a course of Kemenristekdikti and is accredited by BAN PT; (2) have a higher education institution statutes which are fundamental tenets of the organization used as a reference for planning, developing programs and the implementation of functional activities in accordance with the purpose of the higher education institution. In addition statutes contain a reference basis used as a general rule development, academic regulations and operating procedures that apply in the higher education institution concerned; (3) Having a strategic plan for higher education institution. it is important for higher education institution conducting the preparation of a strategic plan as a first step that must be done so that all programs and activities that can be formulated in sync with the challenges faced; (4) have standards and standard run in academic and non-academic. In accordance with the regulations stipulated in the ministry regulation No. 49 in 2015 on the National Standards for Higher Education; (5) report the activities of the learning process throughout the course of each semester to higher education institution Database. (6). Not organized learning activities in a course without permission of govenrment including remote classroom. (7). Does not conduct face to face learning in the form of more than 9 hours per day for a student; (8). Organized by the foundation, association union, or legal entity nonprofit kind that have ratified the authority (for private higher education institution, body Region I North Sumatra organizers PTS or foundation, Union or association has been registered and listed in Ministry of Law and Human Rights; (9) not being institutional conflicts both internally and externally higher education institution.

\section{CONCLUSIONS AND SUGGESTION Conclusion}

Higher education institution of the existing and developing quality, highly dependent on its ability to perform learning organization so, it is proved by still indicated the variation of the quality of the development of higher education quality, from the higher education institution ranks of world-class, clusters of 1 to 5, higher education institutions healthy and unhealthy and even the closure or revoked. With the oragnization learning in higher education is expected to be able to respond to the various internal and external policies on the development of quality education in an adaptive and generative.

By the learning organization in higher education is expected to be able to respond to various internal and external policies on the development of quality education in an adaptive and generative. The higher education institution continues to grow are those that have the capacity to build a vision (vision building), is able to build up qualifications and personal competence in plenary (personal mastery), capable of thinking systems (systems thinking), have a mental model of the innovative (mental models), have the ability learning in a team (team learning) in order to increase the capacity of intelligence for sharing problems, sharing information, sharing, experience, and sharing solution and thus creating a high-quality education is superior cooperative, comparative and competitive in local, national and global. 


\section{Suggestion}

Various suggestions that can be given in writing as a learning organization approach in responding to the development policy of higher education institution in Indonesia cannot be separated addressed to policy makers and policy implementers higher education institution itself. As for suggestions that may be filed, among others:

1. Policies issued by the government, especially Ministry of Higher Education, that would be enforced fairly and proportionately for state and private higher education institution.

2. Government Policy especially Ministry of Higher Education in the delivery of assistance to higher education institution that need to be helped not to higher education institution already established.

3. Terms of the establishment of the higher education institution need to study the feasibility of the airworthiness standards prescribed government,

4. Higher education institutions are less able to better merge with other higher education institutions.

5. Higher education institution should always respond adaptively and generative against government policy in improving the quality of education, research and community service

6. Higher education institution should do the learning organization in translating government policies mainly of Ministry of Higher Education into strategic plans, standard operating procedures, the work program for the development of quality higher education.

\section{REFERENCES}

Armanto, D (2016), Perguruan Tinggi Sehat, Tirto, Medan

Garvin, D. A (2000) Learning in Action. Boston, Harvard Business School Press

Senge, P.M. dkk (2002) The Fifth Discipline, Jakarta, Interaksara

Suprapti,W dan Pranoto, J. (2001). Membangun Kerjasama Tim (Team Building), Jakarta, LAN RI

Morrisey, G.L. (1996), Pedoman Pemikiran Strategis Membangun Landasan Perencanaan Anda, Jakarta, Prenhalindo

Direktur Pembelajaran dan Kemahasiswaan (2016). Perkembangan Perguruan Tinggi di Indonesia. Dies Natalis UNPAR, Bandung

Pangkalan data Perguruan Tinggi, (2016). Perbandingan jumlah Perguruan Tinggi di Indonesia semester 2015/2016. Kemenristek Dikti, jakarta

Surat Keputusan Kemenristek Dikti, Nomor 492 a /Kep/VII/2015 tentang Klasifikasi dan Pemeringkatan Perguruan Tinggi di Indonesia tahun 2013

Kemenristek Dikti (2016). Perguruan Tinggi bermasalah, Tidak memenuhi Indikator Sehat, Ayo Kuliah, Jakarta. 